\title{
EVALUATION OF MORPHOLOGICAL CHARACTERISTICS IN VENEZUELAN MAIZE (Zea mays L.) GENOTYPES UNDER DROUGHT STRESS ${ }^{1}$
}

\author{
R.G. CAMACHO \\ Dep. of Land Sclences and Environment-U.R.G., Guarico, Venezuela \\ D.F. CARABallo \\ Dep. of Chemistry-U.R.G., Guarico, Venezuela
}

\begin{abstract}
A greenhouse experiment was carried out to evaluate the responses among 10 maize (Zea mays $L_{\text {.) }}$ genotypes under drought stress. Seeds were planted in washed sand in plastic pots. The research was established in a completely random design with ten treatments and three replicate pots. The plants were harvested four weeks after sowning, and leaf area per plant (LA), root volume (RV), longest root length (LRL), plant height (PH), fresh (RFW) and dry weight (RDW) of roots, shoot dry weight (SDW), RDW/SDW ratio, and total dry matter production (TDM) were determined. Significant varietal differences for all characters were found, except for LRL. The data obtained allowed to identify Cargill-163 as a poor genotype at low water supply. Danac-3006, FM-6, Sefloarca-91, Ceniap PB-8, and Tocor6n-300 hybrids showed the best behaviour in terms of RDW/SDW ratio and root volume. On the other hand, root dry weight was identified as the best indicator and easiest characteristic to determine the drought-tolerance of maize plant.
\end{abstract}

Key Words: Zea mays, leaf area, root volume, root length, plant height, root weight, shoot weight, total dry matter, drought resistance

\section{AVALIAÇÃO DE CARACTERISTICAS MORPOLOGICAS EM GENOTTIPOS DE MILHOS VENEZUELANOS SOB ESTRESSE DE AGUA}

RESUMO: Foi efetuado um experimento em casa de vegetaçắo para avaliar a resposta de genotipos de milho sob estresse a seca. As sementes foram semeados em potes plásticos com areia lavada. Foi usado um delineamento inteiramente ao acaso com 10 tratamentos e tres repetiçōes. As plantas foram coletadas quatro semanas apos o plantio e determinou-se a área foliar por planta (AF), volume de rázes (VR), comprimento da maior raiz (CMR), altura de planta (AP), peso fresco (PFR) e seco (PSR) de rázes, peso seco da parte aérea (PSPA), relação PSR/PSPA e produção total de matéria seca (PTMS). Foram encontradas diferenças significativas em todos os parametros avaliados, exceto para CMR. Os dados obtidos permitem identificar o CARGILL-163 como o pior genotipo quando submetido a baixo suprimento de agua. Os hibridos FM-6, SEFLOARCA-91, CENIAP PB-8 e TOCORON-300 mostraram o melhor comportamento em termos de relaçāo PSR/PSPA e VR. Por outro lado, PSR foi identificado como o melhor parámetro indicador de plantas tolerantes a estresse à seca.

Describures: Zea mays, área foliar, volume de raízes, comprimento de raizes, altura de planta, peso das raízes, peso da parte aérea, matéria seca total, resistencia a seca

\section{INTRODUCTION}

Maize (Zea mays L.) is a staple food for vast numbers of people around the world. In Venezuela the production of maize is used totally for human food. The crop is adapted to tropical, sub-tropical and temperate areas, but little is known about drought stress response within tropical maize cultivars. By contrast, in the U.S.A., selected types of corn are known for their high yield under condition of limited and uncertain rainfall (MILLER, 1923).

Over the years, physiological and morphological characteristics such as osmotic adjustment, stomatal behaviour, chloroplast activity, leaf water potential, root volume, root

\footnotetext{
' Financial support from Rómulo Gallegos University (U.R.G.), and CONICIT - Guárico. Both Institutions with headquarter in San Juan de los Morros, Guárico, Venezuela.
}

Sci. agric., Piracicaba, 51(3):453-458, set./dez. 1994 
weight, leaf area, dry matter production, have been studied in several maize cultivars grown under limited water supply (MUSICK et al., 1965; SANCHEZ-DIAZ \& KRAMER, 1971; NASS \& ZUBER, 1971; MORGAN, 1984 ; WEERATHAWORN et al., 1992; MIAN et al. 1993). It has been shown that maize has low drought tolerance due its high transpiration surface and poor root system (MALHERBE, 1964).

This paper examines the morphological responses to drought stress of ten corn cultivars, and their relationship to the total dry matter production.

\section{MATERIAL AND METHODS}

Ten genotypes of maize were studied: Danac-3006, Sefloarca-02, FM-6, Ceniap-69, Sefloarca-91, Ceniap PB-8, Danac-9006, Tocorón300 , Arichuna, and Cargill-163. The seeds of the ten genotypes were treated with fungicides to avoid the action of pathogens.

The genotypes used are double cross hybrids, obtained from inbred lines. They were bred for high yields (higher than $4,000 \mathrm{~kg} / \mathrm{ha}$ ) under conditions where water and soil fertility are not limiting factors. Except for the Cargill-163 hybrid, they were all bred in Venezuela. Danac-9006, Sefloarca-02, Ceniap PB-3, Ceniap-69 and Sefloarca91 are hybrids of low height (up to $2.30 \mathrm{~m}$ ); and Danac-3006, Tocorón-300, Arichuna and FM-6 are hybrids of high height (larger than $2.30 \mathrm{~m}$ ).

The experiment was carried out in greenhouse at Rómulo Gallegos University, Venezuela. Thirty plastic pots were filled with $2 \mathrm{~kg}$ of washed sand. Five seeds were planted per pot and the seedlings were thinned to 2 plants per pot, 5 days after emergence.

The pots were irrigated with distilled water before emergence of seedlings, and between the emergence and up to 1 week with $1 / 5$ diluted Hoagland's solution, and thereafter with complete solution. Exactly one-half liter of this solution was added per pot 3 days per week, and adequate amount of water was provided to bring the soil in each try to field capacity. The genotypes all grew under optimal nutrient conditions.

A completely random design with three replications was used in this study. Stress was imposed by decreasing amount of stored soil moisture during the growing season. When the plants were 4 weeks old, the two plants of each pot were harvested and carefully separed into roots and shoots. The root were washed with a $1 \%$ sodium hydroxide solution, to free them from sand particles. The harvested material was then washed with distilled water, wrapped in wet paper towels, and brought to the laboratory where the following data were recorded: leaf area (area in $\mathrm{cm}^{2}$, measured with LI-300, LI-COR, portable area meter), root volume (volume in $\mathrm{cm}^{3}$, measured by water displacement), longest root length (mean length in $\mathrm{cm}$ ), plant height (cm, from soil surface to insertion point of flag leaf), root wet weight $(\mathrm{g})$, root dry weight (g), shoot dry weight (g), and total dry matter production (g).

Means of each treatment were compared according to the Tukey test at the 0.05 significance level. Simple and square regression analysis were calculated among total dry matter and the other variables.

The mean day temperature in the greenhouse was $27.5^{\circ} \mathrm{C}$, with a maximum of $35^{\circ} \mathrm{C}$, measured at $2: 00 \mathrm{pm}$, and a minimum of $20^{\circ} \mathrm{C}$ at 6:00 am. The mean relative humidity was $84.5 \%$, with a maximum of $92 \%$ at $6: 00$ am, and a minimum of $74.55 \%$, measured at $2: 00 \mathrm{pm}$. The diurnal variations of temperature and relative humidity in the greenhouse where monitored with a termohygrometer.

\section{RESULTS AND DISCUSSION}

Considerable differences exist among the com genotypes studied in their ability to endure drought stress. Table 1 show that all genotypes, except for Danac-3006 and Cargill-163, had a consistenly high leaf area growth under water stress conditions. A drought stress during the vegetative stage provokes diminution of the growth in maize crop leaves (VIANELLO \& SOBRADO, 1991). Cargill-163 hybrid showed the lowest total leaf area, lesser to $30 \mathrm{~cm}^{2}$, with the half of leaves senescent. Growth and photosynthesis in young leaves frequently do not reach the original rates for several days, and old leaves are often shed; also, cells are smaller and leaves develop less during water stress, resulting in reduced area for photosynthesis (SALISBURY \& ROSS, 1992).

Clear genotypic differences in the roots were observed among the genotypes (TABLE 1). A group with higher performance of the root volume included the following genotypes: Tocorón-300, Ceniap PB-8, Sefloarca-91, Ceniap-69, FM-6 and Danac-3006; all with means above $7.0 \mathrm{~cm}^{3}$. Another group which showed lower root volume 
was comprised of Sefloarca-02, Danac-9006, Arichuna and Cargill-163 hybrids, with means below $7.0 \mathrm{~cm}^{3}$. High root volume has been used to identify higher corn genotypes (MUSICK et al., 1965), and this characteristic is an indication of the greater ability to permeat a larger volume of soil or to have thicker roots (NOUR et al., 1978).

Differences in plant-height as responses to drought were found among the genotypes studied (TABLE 1). FM-6, Sefloarca-91, Danac-9006 and Arichuna genotypes performed better than Danac3006, Sefloarca-02, Ceniap PB-8 and Tocorón-300; whereas Ceniap-69 and Cargill-163 genotypes were associated with lower plant height. Cellular growth appears to be the most sensitive response to water stress (BOYER, 1970). In dark-grown squash (Cucurbita maxima), decreasing the external water potential by only - $0.1 \mathrm{MPa}$ (sometime less) results in a perceptible decrease in cellular growth (irreversible cell enlargement) and thus in root growth (SAKURAI \& KURAISHI, 1988). Several investigations have reported that water stress imposed during the vegetative growth phase reduces the plant height (BOYER, 1970; BENNET \& HAMMOND, 1983; YANG \& HSIANG, 1992; ABRECHT \& CARBERRY, 1993).

There was no statistically significant variation in longest root length (TABLE 1), a result which could have been caused by using pots insufficiently deep to allow full expression of the character; however, there was a 1.5 fold difference between the smallest (Cargill-163 hybrid) and largest (Tocorón-300 hybrid) root length. HURD (1974) concluded that measurement of roots in boxes of soil in the greenhouse gives a fair approximation of root growth in the field, and that wheat root growth at the seedling stage may therefore be useful in predicting root growth under drought stress at later growth stages.

Under drought, there was little significant differences in root fresh weight among genotypes (TABLE 1). Cargill-163 showed the lowest RFW (2.05 g), while the other nine genetic materials presented higher root fresh weight, with no statistical differences among them. Drought drastically decresead RFW in winter wheat genotypes grown in greenhouse container culture for 3 weeks (MIAN et al., 1993). The trend demonstrated by Cargill-163 may be indicative of a sensitive genotype to drought stress.

When screening the corn genotypes responses for root dry weight under drought stress, it was found that all hybrids, except for both
Ceniap-69 and Cargill-163, performed well without any significant differences among them. MALHERBE (1964) reported that corn genotypes with low root dry weight are less tolerant to drought stress.

As was the case with RDW and RFW, Cargill-163 also showed a low SDW - value (TABLE 1), with mean below $0.50 \mathrm{~g}$, while the other nine genotypes presented the best behaviour in relation to this characteristic, with means between $0.75 \mathrm{~g}$ (Ceniap PB-8) and 0,90 $\mathrm{g}$ (Danac9006). Water stress during the vegetative growth stage decreases SDW in com genotypes (ECK, 1986; VIANELLO, 1988), and consequently decreases the culture productivity (VIANELLO \& SOBRADO, 1991).

As to the RDW/SDW ratio (TABLE 1), one homogeneous group of genotypes included the following cultivars: Danac-3006 (1.40), Sefloarca02 (1.14), Sefloarca-91 (1.03), Ceniap PB-8 (1.23), Tocoron-300 (1.00), and Cargill-163 (1.19). Another group wich presented lower RDW/SDW ratio included the genotypes: Ceniap-69 (0.79), Danac-9006 (0.77), Arichuna (0.88), and FM-6 $(0.88)$. Genotypic ability for high RDW/SDW ratio contribute to drought tolerance. Maize crops are less tolerant to drought than sorghum due to their high shoot dry weight and low root dry weight (MALHERBE, 1964). Cargill-163 demonstrated a different trend to the other characteristics studied; its RDW/SDW ratio was greater under drought, whereas this genotype showed lower RDW $(0.51 \mathrm{~g})$ and SDW $(0.44 \mathrm{~g})$ than other nine genotypes. NOUR et al. (1978) correlated high RDW/SDW ratios of young plants with superior drought resistance in sorghum genotypes. It thus appears that vigorous shoot growth corresponds to vigorous root growth under a wide range of environmental conditions (included drought) and that either variable can be used to select for seedling vigor. However, it may not be indicative of better tolerance of Cargill-163 to drought compared with other nine genotypes. Such result raises doubtes about the relevance of studies on the evaluation of genotypic responses using RDW/SDW ratio under drought stress.

Little genotypic variability was found for total dry matter production. All genotypes, except Cargill-163, showed high ability to accumulate dry matter, with means above $1.30 \mathrm{~g}$ per plant. No statistically significant difference was observed between them. The Cargill-163 hybrid showed the lowest total dry matter with means below $1.00 \mathrm{~g}$. 
TABLE 1 - Mean leaf area per plant (LA), root volume (RV), longest root lenght (LRL), plant height (PH), root fresh weight (RFW), root dry weight (RDW), shoot dry weight (SDW), RDW/SDW ratio and total dry matter (TDM) for 10 maize hybrids grown in sand cultures under drought stress.

\begin{tabular}{lccccccccc}
\hline & LA & RV & LRL & PH & RFW & RDW & SDW & RDW/SDW & TDM \\
Hybrids & $\left(\mathrm{cm}^{2}\right)$ & $\left(\mathrm{cm}^{3}\right)$ & $(\mathrm{cm})$ & $(\mathrm{cm})$ & $(\mathrm{g})$ & $(\mathrm{g})$ & $(\mathrm{g})$ & & $(\mathrm{g})$ \\
\hline Danac-3006 & $74.66 \mathrm{bc}$ & $8.33 \mathrm{ab}$ & $31.67 \mathrm{ab}$ & $48.00 \mathrm{bcd}$ & $5.18 \mathrm{ab}$ & $0.99 \mathrm{a}$ & $0.78 \mathrm{a}$ & $1.40 \mathrm{a}$ & $1.770 \mathrm{a}$ \\
FM-6 & $133.51 \mathrm{a}$ & $7.17 \mathrm{ab}$ & $32.17 \mathrm{ab}$ & $58.83 \mathrm{a}$ & $6.63 \mathrm{a}$ & $0.77 \mathrm{ab}$ & $0.88 \mathrm{a}$ & $0.88 \mathrm{~b}$ & $1.647 \mathrm{a}$ \\
Ceniap-69 & $101.74 \mathrm{ab}$ & $7.33 \mathrm{ab}$ & $31.33 \mathrm{ab}$ & $43.67 \mathrm{~cd}$ & $4.02 \mathrm{ab}$ & $0.60 \mathrm{bc}$ & $0.76 \mathrm{ab}$ & $0.79 \mathrm{~b}$ & $1.367 \mathrm{ab}$ \\
Sefioarca-02 & $107.60 \mathrm{ab}$ & $6.17 \mathrm{~b}$ & $31.33 \mathrm{ab}$ & $48.50 \mathrm{bcd}$ & $5.73 \mathrm{a}$ & $0.91 \mathrm{ab}$ & $0.80 \mathrm{a}$ & $1.14 \mathrm{ab}$ & $1.717 \mathrm{a}$ \\
Sefloarca-91 & $112.59 \mathrm{ab}$ & $8.50 \mathrm{ab}$ & $29.50 \mathrm{ab}$ & $52.67 \mathrm{ab}$ & $6.75 \mathrm{a}$ & $0.70 \mathrm{ab}$ & $0.79 \mathrm{a}$ & $1.03 \mathrm{ab}$ & $1.587 \mathrm{a}$ \\
Ceniap PB-8 & $108.01 \mathrm{ab}$ & $8.17 \mathrm{ab}$ & $28.50 \mathrm{ab}$ & $45.00 \mathrm{bcd}$ & $6.46 \mathrm{a}$ & $0.94 \mathrm{ab}$ & $0.75 \mathrm{ab}$ & $1.23 \mathrm{ab}$ & $1.683 \mathrm{a}$ \\
Danac-9006 & $130.28 \mathrm{a}$ & $5.67 \mathrm{~b}$ & $32.50 \mathrm{ab}$ & $52.00 \mathrm{abc}$ & $4.70 \mathrm{ab}$ & $0.70 \mathrm{ab}$ & $0.90 \mathrm{a}$ & $0.77 \mathrm{~b}$ & $1.600 \mathrm{a}$ \\
Tocoron-300 & $114.19 \mathrm{ab}$ & $10.17 \mathrm{a}$ & $40.83 \mathrm{a}$ & $47.00 \mathrm{bcd}$ & $6.32 \mathrm{a}$ & $0.81 \mathrm{ab}$ & $0.83 \mathrm{a}$ & $1.00 \mathrm{ab}$ & $1.637 \mathrm{a}$ \\
Arichuna & $116.75 \mathrm{ab}$ & $6.17 \mathrm{~b}$ & $29.17 \mathrm{ab}$ & $50.83 \mathrm{abc}$ & $4.57 \mathrm{ab}$ & $0.72 \mathrm{ab}$ & $0.83 \mathrm{a}$ & $0.88 \mathrm{~b}$ & $1.547 \mathrm{a}$ \\
Cargill-163 & $28.25 \mathrm{c}$ & $6.00 \mathrm{~b}$ & $26.17 \mathrm{ab}$ & $40.50 \mathrm{~d}$ & $2.05 \mathrm{~b}$ & $0.51 \mathrm{c}$ & $0.44 \mathrm{~b}$ & $1.19 \mathrm{ab}$ & $0.943 \mathrm{~b}$ \\
\hline
\end{tabular}

Means within each column followed by the same letter are not significantly different at the 0.05 level according to the Tukey test.

It is most likely that any factor which affects the photosyntetic process, will affect the total dry matter (BOYER, 1970; VIANELLO \& SOBRADO, 1991); thus, drought can be causing strong inhibition of the photosynthetic activity in the Cargill-163 genotype. In this cultivar were observed leaves with precocious wilting. DOGGETT (1988) cited that maize leaves subject to drought for a week or more suffered permanent damage to the stomata; and in all cases, the stomatal behaviour was parallel to the photosynthetic activity (BOYER, 1970).

The data obtained allowed to identify Cargill-163 to be the most undesirable genotype under condictions of drought stress. It is possible that this genotype was bred under conditions where water does not constitute a limiting factor. On the other hand, Danac-3006, FM-6, Sefloarca-91, Ceniap PB-8 and Tocorón-300 hybrids could be utilized in a breeding program by their response to drought. These genotypes showed consistently higher values of root volume and RDW/SDW ratio when grown under limited water supply.
TABLE 2 shows correlations between the variables studied and total dry matter production. All variables, except for root volume and RDW/ SDW ratio, were positively correlated with TDM under drought conditions. The lowest correlations were those among total dry matter and the three following variables: leaf area, root lenght, and plant height. These correlations were not above $r=0.55$, but they were significant. These results corroborate the results by CAMACHO \& GARRIDO (Unpublished data) who studied 9 genotypes of Venezuelan maiz, under field conditions, and concluded that plant height is the best indicator to predict grain yield. The present work demonstrated a positive correlations, greater than 0.79 , among total dry matter and the following variables: root fresh weight, root dry weight and shoot dry weight. The correlation between TDM and RDW was 0.866 ; the best of all variables studied. Thus, root dry weight could be used to predict yield under drought stress. In grain sorghum, root weight was identified as the best and easiest characteristic to determine drought-tolerance plants (NOUR et al., 1978). 
TABLE 2 - Regression equations and correlation coefficients between morphological variables and total dry matter for maize hybrids under drought stress.

\begin{tabular}{|c|c|c|}
\hline \multirow[b]{2}{*}{ Variable } & \multicolumn{2}{|l|}{ Total dry matter } \\
\hline & Regression Equation & $\mathbf{r}$ \\
\hline Leaf area & $y=e^{0.034+0.01 L A^{*}}$ & 0.540 \\
\hline Root Volume & $y=1.19+0.05 R V^{\text {n.s. }}$ & 0.295 \\
\hline Root length & $y=0.73+0.026 \mathrm{RL}^{*}$ & 0.501 \\
\hline Plant height & $y=0.24+0.0268 \mathrm{PH}^{*}$ & 0.534 \\
\hline Root fresh weight & $y=0.864+0.0131 R F W^{*}$ & 0.797 \\
\hline Root dry weight & $y=0.466+1.399 R^{-} W^{-}$ & 0.866 \\
\hline Shoot dry weight & $y=0.379+1.507 \mathrm{SDW}^{-}$ & 0.830 \\
\hline RDW/SDW ratio & $y=0.925+1.142 \mathrm{RDW} / \mathrm{SDW}-0,49(\mathrm{RDW} / \mathrm{SDW})^{2 \mathrm{ns.}}$ & 0.240 \\
\hline
\end{tabular}

* Significant at the 0.05 level

** Significant at the 0.01 level

n.s.: not significant.

\section{CONCLUSIONS}

1. The evaluation technique employed in this work using sand cultures was found to have merit as an inexpensive method of screening genotypes for drought resistance.

2) Danac-3006, FM-6, Sefloarca-91, Ceniap PB-8, and Tocorón-300 hybrids showed the best behaviour under drought stress.

3) Cargill-163 hybrid was a poor genotype at low water supply.

4) Root dry weight was identified as the major criterion for selection of maize genotypes under drought conditions.

\section{ACKNOWLEDGMENTS}

The authors thank Professors Antonio Augusto Lucchesi and Eunice Melotto, for reading and improving of the manuscript. Both professors are members of the Escola Superior de Agricultura "Luiz de Queiroz", University of São Paulo, Brazil. And to Nieves Moyetón (Rómulo Gallegos University) for the competent technical assistance.

\section{REFERENCES}

ABRECHT, D.G.; CARBERRY, P.S. The influence of water deficit prior to tassel initiation on maize growth, development and yield. Field Crops Research, Amsterdam, v.31, p.55-69, 1993.

BENNET, J.; HAMMOND, L. Grain yields of several corn hybrids in response to water stresses imposed during vegetative growth stages. Soil and Crop Science Society of Florida Annual Proceedings, Gainesville, v.42, p.107-111, 1983.

BOYER, J.S. Differing sensitivity of photosynthesis to low water potentials in com and soybean. Plant Physiology, Rockville, v.46, p.236-239, 1970.

DOGGETT, H. Sorghum. 2.ed. Harlow: Longman, 1988. 512p.

ECK, H. Effects of water deficits on yield, yield components and water use efficiency of irrigated corn. Agronomy Journal, Madison, v.78, p.1035-1040, 1986.

HURD, E. Phenotype and drought tolerance in wheat. Agriculture Meteorology, Amsterdam, v.14, p.39-55, 1974. 
MALHERBE, 1. The control of soil moisture. In: Soil fertility, Oxford: Oxford University Press, 1964. p.130-137.

MIAN, M.; NAFZIGER, E.; KOLB, F.; TEYKER, R. Root growth of wheat genotypes in hydroponic culture and in the greenhouse under different soil moisture regimes. Crop Science, Madison, v.33, p.283-286, 1993.

MILLER, E.C. Relative water requirements of corn and sorghum. Manhattan: Kansas Agriculture Experiment Station, 1923. (Technical Bulletin, 12).

MORGAN, J.M. Osmoregulation and water stress in higher plants. Annual Review of Plant Physiology, Stanford, v.35, p.299-319, 1984.

MUSICK, G.J.; FAIRCHILD, M.L.; FERGUSON, V.L.; ZUBER, M.S. A method of measuring root volume in com (Zea mays L.). Crop Science, Madison, v.5, p.601-602, 1965.

NASS, H.G.; ZUBER, M.S. Correlation of corn (Zea mays L.) roots early in development to moisture root development. Crop Science, Madison, v.11, p.655-658, 1971 .

NOUR, A.M.; WEIBEL, D.E.; TOOD, G.W. Evaluation of root characteristics in grain sorghum. Agronomy Journal, Madison, v.70, p.217-218, 1978.

SAKURAI, N.; KURAISHI, S. Water potential and mechanical properties of the cell wall of hypocotyles of dark-grown squash (Cucurbita maxima Duch) under water stress conditions. Plant and Cell Physiology, Tokyo, v.29, p.1337-1343, 1988.
SALISBURY, F.B.; ROSS, C.W. Stress physiology. In: Plant Physiology, 4.ed. Belmont: Wodsworth, 1992. p.575-600.

SANCHEZ-DIAZ, M.F.; KRAMER, P.J. Behaviour of corn and sorghum under water stress and during recovery. Plant Physiology, Rockville, v.48, p.613616,1971

VIANELLO, I. Comportamento de três cultivares de maiz (Zea mays L.) sometidos a sequía en el campo. Caracas, 1988. 99p. Tesis (Licenciado) - División de Ciencias Biológicas, Universidad Simón Bolívar,

VIANELLO, I.; SOBRADO, M. Respuestas contrastantes del maiz tropical ante la sequía en el período vegetativo o reproductivo. Turrialba, San Jose, v.41, p.403-411, 1991 .

WEERATHAWORN, P.; SOLDATI, A.; STAMP, P. Seedling root development of tropical maize cultivars at low water supply. Angewandte Botanik, Berlin, v.66. p.93-96, 1992 .

YANG, C.M.; HSIANG, W.M. Growth and reproduction of maize (Zea mays $L$. cv. Tainung $n^{\circ} 1$ ) response to soil water deficits. I. Changes of growth when stress and recovery occurring at the vegetative stage in the controlled environment. Journal of Agricultural Research of China, Taiwan, v.41, p.132-139, 1992.

Recebido para publicaçăo em 01.04 .94

Aceito para publicação em 12.07 .94 